\title{
The Implementation Analysis of Clinical Governance by the Medical Committee at Deli Serdang Hospital
}

\author{
$\underline{\text { Ratna Wulandari }{ }^{1} \text {, Zulfendri }{ }^{2} \text {, Surya Utama }}{ }^{2}$ \\ ${ }^{1}$ Master Student in Faculty of Public Health, Universitas Sumatera Utara, Medan, Indonesia \\ ${ }^{2}$ Lecturer in Department of Administration and Health Policy, Universitas Sumatera Utara, Medan, \\ Indonesia \\ Email: ratnawulandari.dr@gmail.com
}

\begin{abstract}
:
Clinical governance aims to maintain and improve the quality of medical services for patients and protect patients from the risk of unexpected events as regulated in Law Number 44 of 2009 concerning Hospitals and Minister of Health Regulation Number 755 / MENKES / PER / IV / 2011 regarding the implementation medical committee at the hospital. The medical committee is one of the hospital's instruments that has an important role in implementing clinical governance so that the medical staff at the hospital is maintained professionally. In implementing clinical governance in hospitals, it is done by carrying out credentials, monitoring the quality of the medical profession, and maintaining the ethics and discipline of the medical profession. This type of research is qualitative in-depth interviews. Informants were selected using a purposive technique. The subjects in this study were informants relating to the medical committee. The results showed that the implementation of clinical governance in Deli Serdang Hospital was not going well. This can be seen from the implementation of medical committee activities that are not in accordance with the Minister of Health Regulation No. 755 / MENKES / PER / IV / 2011 concerning the implementation of medical committees in hospitals. The work program carried out by the medical committee at Deli Serdang Hospital is deemed not in accordance with the expected target. This is due to the lack of planning and budget that supports the implementation of clinical governance in Deli Serdang Hospital. The implementation of clinical governance by the medical committee in medical services at Deli Serdang Hospital has not been running well. Thus, good planning and budgeting is needed to strengthen the activities of the medical committee in achieving good clinical governance in Deli Serdang Hospital.

Keywords:

clinical governance; hospital
\end{abstract}

\section{Introduction}

Health as a component that is very meaningful to humans. With a healthy body, humans will be able to carry out their activities productively. Everyone has a desire for a healthy body, therefore to realize a healthy state, there are several things that must be done, including the existence of health services aimed at the community. One of the efforts to provide health services by the government to the community is the hospital. According to Yulisnawati (2020) the medical risk due to surgery in developing countries is 19 percent higher when compared to developed countries, and 25 percent of the drugs used in developing countries are fake. Of the 20 countries surveyed by WHO, 60 percent of patient safety incidents and the use of fake drugs occur in developing countries.

Law of the Republic of Indonesia Number 44 Year 2009 regarding Hospitals Article 29 explains that every hospital has the obligation to provide safe, quality, anti-discrimination and effective health services by prioritizing the interests of patients in accordance with 
hospital service standards. Hospital is a health service institution that carries out individual health services in a complete manner through inpatient, outpatient and emergency care services. Health services carried out in hospitals as an advanced service level need to carry out better services than Community Health centers. People who need treatment to the hospital have a good desire from the health services they receive for the recovery of their illness. Because the community thinks that the quality of the service it receives at the hospital is definitely better and quality with the support of infrastructure, the medical staff at the hospital in dealing with the health problems they experience.

At present the hospital has become a health-intensive, capital-intensive and laborintensive healthcare company. This is because the hospital employs a large number of Human Resources, a variety of competencies and professions. Hospitals as institutions that provide health services must comply with technological advances in the current global era, therefore it is necessary to compete well with other hospitals in order to realize good quality services for people in need (Muninjaya, 2015).

Improving the quality of health services is one of the key factors in improving hospital services. The hospital performs health services, where the quality of health services is the main parameter for the progress of the hospital. Good and bad health implementation system in a hospital is very much influenced by the performance of medical staff at the hospital. In improving service quality, good clinical governance is quite effective, especially in the context of creating services that are focused and oriented to patient safety (Menap, 2018).

Patient safety is an effort to prevent the occurrence of errors in providing health care measures that can endanger patients. Every health worker has the risk to make mistakes in providing health services that can threaten the safety and harm the patient. Errors of action can occur in all lines of health services in all countries in the world both in developed and developing countries (WHO, 2015).

Various countries report the incidence of patient safety in hospitals every year in detail. The National Patient Safety Agency reports that in the January-December 2016 period the number of reported patient safety incidents from the United Kingdom was 1,879,822 incidents. Ministry of Health Malaysia in 2013 reported the number of patient safety incidents in the JanuaryDecember period of 2,769 incidents and for the country of Indonesia in the 2006-2011 period the Hospital Patient Safety Committee reported 877 patient safety incidents (Menap, 2018).

One of the efforts of the hospital in carrying out its duties and responsibilities to maintain patient safety is to maintain the professional standards and competencies of doctors who perform medical actions against patients in the hospital. The most relevant hospital device for implementing clinical governance so that medical staff in the hospital is maintained professionalism is the medical committee. This is in accordance with the Regulation of the Minister of Health of the Republic of Indonesia Number 755/Menkes/Per/IV/2011 regarding the implementation of medical committees in hospitals. According to the Minister of Health, the medical committee is a hospital unit in implementing clinical governance so that doctors at the hospital are protected by professionalism through the control of doctors who provide health services at the hospital. Professionalism in the service can be realized through the administration of credentials for all doctors who provide health services in hospitals, the procedures for maintaining physician quality and the procedures for maintaining discipline, ethics, and medical professional behavior. The circular Medical Committee to implement good clinical governance is expected to improve the quality of health services and patient safety in hospitals better (Kemenkes, 2011). 
Deli Serdang Lubuk Pakam Hospital is a Regency-class B type hospital and is a teaching hospital for several universities in North Sumatra province. Every medical service performed by medical staff always has at least two sides of influence, namely the success or failure of therapy. Among those that are quite sad is in the teaching hospital the value of medical error that can make therapy fail to reach more than $6.5 \%$. Research by monitoring in special care, Avelling (2015) concluded that medical errors occur in 1.7 patients per day. This implies that at least one day a patient will have a risk due to medical error almost twice.

\section{Review of Literature}

\subsection{Clinical Governance}

Good hospital governance is the application of hospital management functions based on the principles of transparency, accountability, independence and responsibility, equality and fairness. Good clinical governance is the application of clinical management functions that include clinical leadership, clinical audits, clinical data, evidence-based clinical risk, performance improvement, complaint management, monitoring mechanisms for service outcomes, professional development, and hospital accreditation (Law Number 44 of 2009).

Clinical governance or clinical governance, is an effort to improve the quality of clinical services in hospitals. Clinical governance is a method that protects organizations that conduct medical services to continuously carry out efforts to change towards quality services and must perform medical services in accordance with high enough standards by prioritizing excellent service and prioritizing patient safety (KARS, 2012).

The purpose of hospital governance in general is to maintain and improve the quality of health services for patients where this governance is considered accountable for its implementation. The objectives of Good Clinical Governance according to Rahmawati (2017) are: (1) Ensuring access to adequate and high quality medical activities; (2) The best care for all patients served; (3) Protect patients from unexpected risks.

\subsection{Medical Committee}

The most relevant hospital device for implementing clinical governance so that medical staff in the hospital is maintained professionalism is the medical committee. The Medical Committee is a non-structural organization in hospitals that aims to ensure the implementation of good, professional medical services, which always refers to the interests of patients, as well as paying attention to the Medical Code of Ethics and Hospital Code of Ethics and the norms that apply to Indonesian society. The medical committee in implementing clinical governance in hospitals is carried out through the mechanism of credentials, maintaining the quality of the medical profession, and maintaining the ethics and discipline of the medical profession (Ministry of Health, 2011).

The medical committee carries out its duties through three main things, namely: (1) recommendations for granting permission to conduct medical services (entering to the profession), carried out through a subcommittee of credentials; (2) maintaining competency and behavior of medical staff who have obtained permits (maintaining professionalism), carried out by the professional quality subcommittee through medical audits and continuing professional development (continuing professional development); (3) recommendations for the suspension of certain clinical authorities to revoke licenses for medical services (expelling from the profession), are carried out through the subcommittee on ethics and professional discipline (Ministry of Health, 2011). 


\section{Research Method}

This research is a qualitative type of research with domain analysis. Domain analysis is the first step in conducting qualitative research with the aim to describe in general and the overall description of the research object in this case is the analysis of the implementation of clinical governance by the medical committee at Deli Serdang Hospital. The study was conducted at Deli Serdang Hospital. The choice of location is based on the consideration that Deli Serdang Lubuk Pakam Hospital is a district-class B hospital and is a teaching hospital for several universities in North Sumatra province and no research has been conducted on clinical governance at Deli Serdang Hospital.

\section{Discussion}

The medical committee is a hospital device that implements clinical governance so that medical staff is maintained professionally through credential mechanisms, maintaining the quality of the medical profession and maintaining ethical discipline and the medical profession. The medical staff referred to in this case are doctors, dentists, specialists and specialist dentists in a hospital. The purpose of establishing a medical committee is to organize good clinical governance so that the quality of health and patient safety services is more guaranteed and protected. The implementation of clinical governance in this study was divided into three parts of governance, namely (1) governance of credentials; (2) Professional quality management; and (3) professional ethics / discipline management.

\subsection{The Implementation of Clinical Governance in Credential Management}

The medical committee functions to uphold professionalism by controlling the medical staff in the hospital. This is done to maintain patient safety by maintaining the standards and competencies of medical staff who interact directly with patients. For this reason, a hospital needs to verify the competence of a medical staff, even though it has obtained a specialized brevet from the relevant medical college.

Based on the Republic of Indonesia Minister of Health Regulation No. 755/MENKES /PER/IV/2011, the credential process is carried out for two main reasons. The first reason, many factors affect competence after a person gets a competency certificate from a collegium. Basically medical science is a science that is constantly experiencing development. Therefore, a medical staff is required to be able to follow the existing developments. This is necessary to ensure the safety and satisfaction of patients when utilizing health services at the hospital.

The second reason, namely the state of a person's health can be decreased due to certain diseases or increasing age, thereby reducing the security of medical services they do. It can be seen that without adequate competency enhancement, of course it is very difficult to meet these demands. The hospital's actions in overcoming these two main reasons are recognized by the credentialing mechanism. After a medical staff member is declared competent, the hospital then issues a license called clinical authority (clinical privilege).

The implementation of credential procedures at Deli Serdang Hospital based on the results of the study is known to have not gone well. This is proven by the statement of the research informant stating that "The credential process for doctors working here has not been carried out routinely". Furthermore, according to another informant, it is known that "credentialing for doctors does not work as expected. Credentialing is carried out only as a complement to hospital and BPJS accreditation documents. Because if there is no credential 
document, then medic services from BPJS cannot be disbursed. If the nurse is already running".

Inadequate credentials management causes the list of clinical authorities that medical staff should have as incomplete as they should. This can be proven based on the statement of research informants that "Details of clinical authority for doctors already exist. But it is not complete for all doctors who work ". This is also reinforced by another statement that "In my opinion, there is no detailed list of clinical authority of every doctor. I have already said that the stages are not just for the collection of files, but the list of clinical authority is to see the competence of each doctor, because each doctor has different competencies even though the same specialist. But the reality is not done ".

The above description shows that the management of credentials at Deli Serdang Hospital has not yet proceeded with the mandate of the Minister of Health Republic of Indonesia No 755 / MENKES / PER / IV / 2011. Credentials are important requirements that must be fulfilled for medical personnel before conducting medical services to patients. Credentialing is a process to meet standards as an effort to prioritize patient safety, have good competence and accountability so that they can provide professional and quality services (Dyah, 2018). Thus, the implementation of credential governance is very important to consider a hospital in ensuring the competency of its medical staff.

\subsection{The Implementation of Clinical Governance in Professional Quality Management}

The quality of health services provided by hospitals to patients is of course very much determined by the competence of all the assigned medical staff. Professional quality management in this case exists to monitor and control the professional quality of medical staff. Basically, the quality control of this profession has three important aspects that must be considered by hospitals, namely recommending continuing education and medical audits.

Based on the results of research with all informants about professional quality management, a summary was obtained that Deli Serdang Hospital has conducted various activities such as seminars, workshops and training. However, the implementation based on the information from the informants above has not gone well. This is due to the lack of coordination of hospital management, medical committees and medical staff in the implementation of existing training. This is evidenced by the statement of the informant that "It is carried out but not too often as a training or seminar. If there are training, seminars or courses that want to participate submit to the hospital. If there are costs financed by the hospital, but if there are no costs then the costs themselves ". The statement explained that planning and budget allocation support was not good enough in upholding the work program of the medical committee. This is certainly one of the obstacles possessed by the hospital so there are still many clinical governance programs that are not running properly.

The conduct of medical audits has also not been carried out properly. This is evidenced by the statement of the informant that "Every hospital that should provide services to patients conduct medical audits for working doctors. It's been done here, but it doesn't run routinely. Maybe only for accreditation purposes. Further information was added with other informants that "For medical audits we have already done it to a number of doctors who indeed felt the need for supervision. Indeed, the implementation is not routinely done. Still very lacking". The information shows that the implementation of medical audits still needs to be improved. Given the important purpose of conducting medical audits is to maintain the professional quality of every medical staff in order to be able to provide the best service to patients. Medical audits are not used to suspect the presence or absence of errors from 
medical staff in certain cases. But this medical audit is carried out to find out whether the medical services provided to patients are carried out in accordance with established standards. Without the implementation of a medical audit, it is very difficult to know the conditions and competencies of the medical staff are still relevant or not with the development of medical science at this time.

Based on the discussion above, it can be concluded that professional quality management related to policies and procedures of the work mechanism of the medical committee has not been implemented properly in Deli Serdang Hospital. This is because the activities or agendas carried out by the professional quality sub-committee have not been wellplanned in relation to what will be done, who the targets are and what outputs they will produce, both in conducting medical audits, scientific meetings and continuing education.

\subsection{Implementation of Clinical Governance in Professional Ethics and Discipline}

The success of medical staff is certainly not only seen based on competence, but also based on ethics and professional discipline they have. A medical staff must have good work ethics and professionalism. When interacting with patients or the patient's family, a medical staff should uphold friendliness so as to increase patient comfort in health care.

Efforts to increase the professionalism of medical staff are carried out by implementing medical professionalism development programs and efforts to discipline the behavior of medical staff in the hospital environment. Benchmarks used as guidelines for disciplining the behavior of professional staff of medical staff according to the Ministry of Health Regulation 755 of 2011, namely:

a. guidelines for medical services in hospitals

b. service work procedures at the hospital

c. list of clinical authorities in the hospital

d. guidelines for qualification requirements for conducting medical services (white paper) in hospitals

e. Indonesian medical code of ethics

f. guidelines for medical professional behavior (a book to organize good medical practices)

g. guidelines for violations of medical disciplines that apply in Indonesia

h. medical / clinical service guidelines

i. standard operating procedures for medical care.

Ethical guidance for medical staff at Deli Serdang Hospital has not been carried out properly because it is still done internally and is not carried out routinely. It is further known that professional ethics guidance is carried out internally using Whatsapp group media. This condition is caused by several obstacles such as different levels of activity that make it difficult to determine an appropriate meeting schedule. In addition, the seniority factor is also considered to cause a sense of reticence from the medical committee in delivering a reprimand to the medical staff concerned. This is evidenced by the statement of respondents that "Ethical guidance for doctors here has not run optimally. The quantity and quality are still considered to be very lacking ". Another statement was added by another informant that "We will resolve this more through internal meetings or use a special Whatsapp group because we will deal with sensitive matters. However, if we need a letter of recommendation we will still issue it even though we rarely do it actually because we are both guarding it. Indeed, we have more to complete in deliberations, meaning we do not have to issue disciplinary letters for suspension or the like. But there are some cases of management taking over it. So the decision is direct management to the doctor concerned without passing the medical committee. The 
medical committee only knows about the latest decisions that have been made. It should go through the medical committee, so there is still a problem with the management system collision. Yes, it's understood because sometimes the seniority factor still influences."

Furthermore it was found that professionalism development was considered still not good. These coaching activities have been carried out and differentiated for each doctor's expertise in the hospital, for example training for emergency room doctors and other doctors. This is supported by the statement of respondents that "Professionalism development is done but it is still not routine. Activities in the form of symposiums or seminars ". Other information given by the informant shows that walking professional development, both from the medical itself, the medical and also the structure of training activities such as for emergency room doctors, room doctors or other doctors. Coaching tailored to his specialization. But it is not optimal".

Improvements to the discipline of the professional behavior of medical staff at Deli Serdang Hospital should be based on the 9 benchmarks above according to the mandate of the Republic of Indonesia Minister of Health number 755 2011. To meet the overall benchmarks above the hospital must complete every required document such as internal hospital regulations, list of authority's clinical, service work procedures, standard operational procedures for medical care and others.

Based on the results of the discussion above, it can be concluded that the ethical management and professional discipline have not gone well. This is because Deli Serdang Hospital has not established policies and procedures for all work mechanisms, such as guidance material, systematic determination of the source of reports, the conduct of examinations and the implementation of disciplinary actions based on SOP in accordance with Permenkes. The obstacle found in the field was the busyness of each member of the medical committee which was not the same, making it difficult to hold regular meetings. Besides that, the lack of coordination and interaction between members of the medical committee and the medical committee with the leadership and management of the hospital results in poor performance.

\subsection{Obstacles to the Medical Committee in the Implementation of Clinical Governance}

Clinical governance is a system that guarantees that the health service provider organization is responsible for continuously improving the quality of its services and guarantees providing services with high standards by creating an environment where excellent service will develop (KARS, 2012).

The results of interviews with all research informants found that the budget in carrying out the medical committee work program is available, but the amount of available budget is not known with certainty. Providing incentives for medical staff in hospitals according to an informant's statement is TPP (additional employee income) and medical services. TPP is given routinely every month by the local government, but for medical services they have to wait for disbursement from the BPJS. The distribution of medical services is not transparent.

Budget allocation in the implementation of clinical governance is one thing that is very important and influences the effectiveness of policy implementation. According to Marlizaini (2017) the limited budget available causes the quality of public services to be provided to the community is also limited. Due to the lack of incentives given to policy implementers, it can cause policy actors not to be able to carry out their duties and functions optimally. Without an adequate budget, it cannot be denied that it will provide a special obstacle for the medical 
committee in carrying out its activities.

Minister of Health Regulation number 755 of 2011 regarding the Implementation of the Medical Committee states that (1). Medical committee members are entitled to get incentives in accordance with the financial ability of the hospital, (2). The implementation of medical committee activities is funded by the hospital budget in accordance with applicable regulations.

The results of interviews with all informants revealed that the number of human resources (medical committees and medical sub-committees) in Deli Serdang Hospital was in the sufficient category. Based on Deli Serdang Hospital profile in 2017 it is known that the number of hospital human resources for specialist / specialist doctors is 50 people, general practitioners / dentists as many as 28 people, part time sub-specialist 4 people, 6 non-nursing medical personnel, 126 nursing staff, 126 personnel other health as many as 90 people and non-medical personnel as many as 40 people. The number of human resources according to one informant was sufficient for hospitals with type B determined based on the Republic of Indonesia Decree Number: 405 / MENKES / SK / IV / 2008. Even though the number of human resources available is also excessive, but to run a medical committee, there are constraints caused by adjusting the difficult time due to the busy schedule of each doctor. There is an informant who stated that each section is running even though the communication intensity is more using whatsapp group media. However, it is generally stated that lack is caused by each doctor having a busy schedule and not having a suitable time to hold a discussion or meeting.

Aside from that, the work plan of the medical committee at Deli Serdang Hospital in implementing the clinical procedure is already in place, but the plan has not been made and implemented properly, so they do not know what activities are the priorities. This causes the activities that have been running also not carried out according to the goals and objectives to be achieved. Planning is the first step in a management cycle. Planning determines the success or failure of the management function. Planning is needed to match performance results with organizational goals to be achieved. As with medical committees, planning is needed with the aim that the duties and responsibilities imposed can be realized clearly.

Medical committee through clinical governance is one alternative that can be developed by hospitals in improving the quality of health services (Ministry of Health, 2011). Based on the information above it can be seen that planning in the medical committee is very important with the aim of achieving success in improving the quality of health services for patients.

Without the planning function, other management functions will have no meaning, because without planning there is no organizing, actuation (mobilization), and supervision work. Therefore, the planning function becomes the basic foundation for other management functions. With the planning, activities in management can be carried out efficiently and effectively, so that it can help achieve the goals set.

Based on the above discussion, it can be concluded that the planning of implementing clinical governance in Deli Serdang Hospital has not been made according to existing regulations, namely Permenkes Number 48 of 2018, so that the priority of activities is also not in accordance with its objectives. In the absence of work plans from the medical committee, the hospital cannot budget how much the budget will be provided to carry out the medical 
committee's work program in implementing good clinical governance.

Thus, improper budget allocation and improper work planning caused the implementation of clinical governance in Deli Serdang Hospital to not run properly. Therefore, improvements are needed to determine an appropriate budget and re-plan for each medical committee's activities to be carried out.

\section{Conclusion}

The implementation of clinical governance in Deli Serdang Hospital has not gone well if it is seen based on the mechanism of credentials, maintaining the quality of the medical profession, and maintaining the ethics and discipline of the medical profession. Various corrective steps are needed to improve the performance of the existing medical committee. However, an important priority according to researchers that must be considered is the planning and determination of the budget allocation of the medical committee's work program. This is due to the two points being an important basis that must be met in carrying out each work program of the medical committee.

\section{References}

Aveling, E.-L., Kayonga, Y., Nega, A., \& Dixon-Woods, M. (2015). Why is Patient Safety so Hard in Low-Income Countries? A Qualitative Study of Healthcare Workers' Views in Two African Hospitals. Globalization and health, 11(1), 6.

Dyah, 2018. Evaluasi Pelaksanaan Kredensialing Dokter Umum Di Rumah Sakit Yogyakarta. Jurnal Magister Manajemen Rumah Sakit-Universitas Muhammadiyah. Yogyakarta.

Kementerian Kesehatan RI, 2011. Peraturan Menteri Kesehatan Republik Indonesia Nomor 755/Menkes/PER/VI/2011 tentang Penyelenggaraan Komite Medik di Rumah Sakit, Jakarta: Kementerian Kesehatan Republik Indonesia.

Kementerian Kesehatan RI, Komisi Akreditasi Rumah Sakit (KARS). 2012. Standar Akreditasi Rumah Sakit. Jakarta.

Kementerian Kesehatan RI, 2017. Peraturan Menteri Kesehatan Republik Indonesia Nomor 48 tahun 2017 tentang Pedoman Perencanaan dan Penganggaran Bidang Kesehatan. Jakarta: Kementerian Kesehatan Republik Indonesia.

Marlizaini. 2017. Analisis Pelaksanaan Peran Komite Medik Dalam Upaya Peningkatan Utilisasi Pelayanan Rawat Inap Di Rumah Sakit Umum Daerah Sijunjung. Tesis Program Pasca Sarjana Universitas Andalas.

Menap, 2018. Manajemen Risiko Klinik. Yogyakarta: Husada Mandiri.

Muninjaya, G.A. 2015. Manajemen Mutu Pelayanan Kesehatan. Jakarta: Penerbit Buku Kedokteran EGC.

Peraturan Internal Tenaga Medik RSUD Deli Serdang, 2016

Undang-Undang RI Nomor 44 Tahun 2009 tentang Rumah Sakit.

Yulisnawati, et al (2020). Nurse's Perception of Patient Safety Culture in an Effort to Improve Service Quality in the Operating Room of Riau Province Hospital. Britain International of Exact Sciences Journal, 2(1): 84-94.

World Health Organization. 2015. World Alliance for Patient Safety. Geneva. WHO. 